\title{
Combined U-Pb and Lu-Hf isotope analyses by laser ablation MC-ICP-MS: methodology and applications
}

\author{
MASSIMO MATTEINI ${ }^{1}$, ELTON L. DANTAS ${ }^{2}$, \\ MARCIO M. PIMENTEL ${ }^{2}$ and BERNHARD BÜHN ${ }^{2}$ \\ ${ }^{1} \mathrm{CNPq}$ and Instituto de Geociências, Universidade de Brasília, Campus Darcy Ribeiro \\ Asa Norte, 70910-900 Brasília, DF, Brasil \\ ${ }^{2}$ Instituto de Geociências, Universidade de Brasília, Campus Darcy Ribeiro \\ Asa Norte, 70910-900 Brasília, DF, Brasil \\ Manuscript received on September 23, 2008; accepted for publication on July 8, 2009
}

\begin{abstract}
The Lutetium-Hafnium isotopic system represents one of the most innovative and powerful tools for geochronology and isotopic studies. Combined U-Pb and Lu-Hf in situ analyses on zircon by LA-MC-ICP-MS permit to characterize isotopically the host magma from which it crystallized furnishing significant information for sediment provenance and crustal evolution studies. In this paper we describe the Lu-Hf systematic by LA-MC-ICP-MS developed in the laboratory of Geochronology of the University of Brasilia and report the results obtained by repeated analyses of ${ }^{176} \mathrm{Hf} /{ }^{177} \mathrm{Hf}$ isotopic ratio of three zircon standards: GJ-1 $=0.282022 \pm 11(\mathrm{n}=56)$, Temora $2=0.282693 \pm 14$ $(\mathrm{n}=25)$ and $\mathrm{UQZ}=0.282127 \pm 33(\mathrm{n}=11)$. The ${ }^{176} \mathrm{Hf} /{ }^{177} \mathrm{Hf}$ ratio $(0.282352 \pm 22, \mathrm{n}=14)$ of gem quality zircon used as in-house standard have been also characterized. As a geological application, we analyzed two complex zircons selected from a migmatitic rocks from the Borborema Province, NE Brazil. On the basis of U-Pb and Lu-Hf data, two main crystallization events have been identified in both studied zircons. An older event at ca. 2.05 Ga recognized in the inherited cores represents a well-characterized paleoproterozoic magmatic event that affected the whole Borborema Province. A second crystallization event at $\sim 575 \mathrm{Ma}$, recognized at the rims, represents a Neoproterozoic (Brazilian) high grade metamorphic-magmatic event.
\end{abstract}

Key words: LA-MC-ICP-MS, Lu-Hf, U-Pb, zircon, Borborema Province.

\section{INTRODUCTION}

During the last decade, the rapid progresses in Inductively Coupled Plasma mass spectrometry (ICP-MS), combined with the new techniques for in situ laser ablation microanalysis, made the Lutetium-Hafnium isotopic system one of the most innovative and powerful tools for geochronologic and isotopic studies. (Thirlwall and Walder 1995, Vervoort and Blichert-Toft 1999, BlichertToft and Albaréde 1997, Gerdes and Zeh 2006, 2009, Griffin et al. 2000, 2002, Hawkesworth and Kemp 2006, Woodhead et al. 2004, Zeh et al. 2007).

Correspondence to: Massimo Matteini

E-mail: massimo@unb.br
The significance of the Lu-Hf method on zircon grains, when combined with the U-Pb method, is the possibility to characterize isotopically the host magma from which they crystallized. The geological applications of this information are numerous. Firstly, in sediment provenance studies the $\mathrm{Hf}$ isotopes yield isotopic constrains on the origin of detrital zircons and consequently of the host sediments. The different Hf isotope signatures, found in a zircon population or even in a single zircon, permit to characterize different magmatic or high-T metamorphic events succeeding in time during the crustal evolution of the source regions (Gerdes and Zeh 2006, Zeh et al. 2007). 
In this paper we describe in detail the analytical systematic of the Lu-Hf method for LA-MC-ICP-MS on zircon, developed in the Laboratory of Geochronology of the University of Brasília.

We show Hf isotope analyses obtained for three standard zircons (GJ-1, Temora 2 and UQ Z6) and for a gem quality zircon that would represent a potential inhouse standard.

We also present an application of this methodology for studying a geological problem in an area of the Borborema Province, Rio Grande do Norte. Combined $\mathrm{U}-\mathrm{Pb}$ and Lu-Hf analyses, associated with backscattering imaging (BSI), have been carried out on two selected zircons separated from a leucosome portion of a migmatitic rock associated to a paleoproterozoic terrane. Several authors (Dantas et al. 1999, 2004) identified in this sector of the Borborema Province multiple orogenic/metamorphic events of archean to paleo- and neoproterozoic ages.

\section{STATE OF THE ART}

\section{THE LU-HF Isotope System}

The Lu-Hf isotope system consists of the spontaneous decay of unstable radionuclide ${ }^{176} \mathrm{Lu}$, by $\beta$-emission, to the stable ${ }^{176} \mathrm{Hf}$ with a half-life of $37.2 \mathrm{Ga}$. The element $\mathrm{Lu}$ is the heaviest Rare Earth Element, belonging to the Lantanides group. It has two natural isotopes: the stable isotope ${ }^{175} \mathrm{Lu}$ and the radioactive isotopes ${ }^{176} \mathrm{Lu}$, representing $97.41 \%$ and the $2.59 \%$ of the natural $\mathrm{Lu}$ isotope abundance respectively. Hafnium is a High Field Strength Element (HFSE) and belongs to the Lithophile group IVa of the periodic table. It has six isotopes: ${ }^{176} \mathrm{Hf},{ }^{177} \mathrm{Hf},{ }^{178} \mathrm{Hf},{ }^{179} \mathrm{Hf}$ and ${ }^{180} \mathrm{Hf}$, all being stable non-radiogenic except for ${ }^{176} \mathrm{Hf}$.

The abundance of the isotope ${ }^{176} \mathrm{Hf}$ on Earth is variable due to the radioactive decay of ${ }^{176} \mathrm{Lu}$, and in the literature it is conventionally compared to the ${ }^{177} \mathrm{Hf}$. The equation

$$
\begin{gathered}
\left({ }^{176} \mathrm{Hf} /{ }^{177} \mathrm{Hf}\right)_{\mathrm{t}}= \\
\left({ }^{176} \mathrm{Hf} /{ }^{177} \mathrm{Hf}\right)_{0}+\left({ }^{176} \mathrm{Lu} /{ }^{177} \mathrm{Hf}\right)_{\mathrm{t}} *\left(\mathrm{e}^{\lambda \mathrm{t}}-1\right)
\end{gathered}
$$

represents the basic age equation for Lu-Hf method, where $t$ is the elapsed time from the closure of the system, and $\lambda$ is the decay constant of ${ }^{176} \mathrm{Lu}$. Different values for $\lambda$ have been proposed in the past by several authors. Patchett and Tatsumoto (1980) proposed the value $1.94 \times 10^{-11} \mathrm{y}^{-1}$, calculated from the slope of a Lu-Hf isochron for eucrite meteorites of known age. In the following, Sguigna et al. (1982) modified the $\lambda$ value to $1.93 \times 10^{-11} \mathrm{y}^{-1}$. Recently, Scherer et al. (2001) proposed the new value of $1.86 \times 10^{-11} \mathrm{y}^{-1}$ obtained by calibration against the U-Pb decay system, which is in agreement with the value obtained by Nir-El and Lavi (1998) using the decay scintillation counting method.

The application of Lu-Hf systematic to geosciences was developed since 1980 when Patchett and Tatsumoto (1980) and Patchett et al. (1981) used TIMS to measure the respective isotopes. However, due to the high ionisation potential of hafnium $(6.65 \mathrm{eV})$, the TIMS method required large sample sizes and a high purity ion exchange separation in order to achieve acceptable results. In the last decade, the new MC-ICP-MS method, which permits excellent ionisation on impure sample solutions, became the best method for Hf isotope analysis. The laser ablation technique coupled with MCICP-MS permitted to analyze solid samples, as mineral grains, with high spatial resolution. The mineral zircon is considered a privileged mineral for isotope analyses of the Lu-Hf system (as for U-Pb system) due to the combination of physical-chemical characteristics and to the capability to host trace and Rare Earth Elements in its crystalline structure (Kinny and Maas 2003, Woodhead et al. 2004). Moreover, zircon is a common accessory mineral, which is present in a great variety of rocks, usually preserving a very complex growing history.

An advantage to use the Lu-Hf method is that Hf, having a geochemical behavior very similar to zirconium, is much more compatible for zircon than Rare Earth Elements (REE), especially Lu. Thus, Hf may reach a higher concentration (up to $3 \%$ ) and is retained more easily than $\mathrm{Lu}$ in the zircon lattice.

For this reason, zircons are characterized by very low ${ }^{176} \mathrm{Lu} /{ }^{177} \mathrm{Hf}$ ratios $(<0.001)$ and, consequently, the isotopic variations of $\mathrm{Hf}$ due to the radiogenic ${ }^{176} \mathrm{Hf}$ are practically negligible. The main corollary of this is that zircons preserve the initial ${ }^{176} \mathrm{Hf} /{ }^{177} \mathrm{Hf}$ isotopic ratios inherited by the magma where they crystallized.

This characteristic, together with the high content of $\mathrm{Hf}$ and its very low diffusivity in zircon, permits to 
preserve, in a single crystal, different Hf isotopic composition, generated during crystal growing under the variable $\mathrm{P}, \mathrm{T}$ and compositional conditions. Experimental calibrations showed that zircon has the closing temperature for Lu-Hf system $200^{\circ} \mathrm{C}$ higher than $\mathrm{U}-\mathrm{Pb}$ system (Cherniak et al. 1997, Cherniak and Watson 2000), indicating that the Hf isotope system remains closed during most of the thermal events after the crystallization of zircon.

\section{Lu-HF Evolution in the Earth's CRUst and Mantle}

The Lu-Hf isotope system is utilized to study the history of differentiation of the Bulk Silicate Earth (BSE) that led to the formation of the crust-mantle system. This isotope system has a systematic that is very similar to the Sm-Nd system, with some fundamental exceptions. The first is that, while Sm and Nd are both Rare Earth Elements with very similar chemical characteristics, $\mathrm{Lu}$ and Hf are a Heavy Rare Earth Element (HREE) and a HFSE, respectively. This implies in a very different behavior for $\mathrm{Lu}$ and $\mathrm{Hf}$ during the evolution of the crustmantle system. Hf is more incompatible than Lu during the partial melting processes in the mantle; so, during the first events of juvenile crust generation in the archean time, the crust has been enriched in $\mathrm{Hf}$ and depleted in $\mathrm{Lu}$, leaving a mantle enriched in $\mathrm{Lu}$ and depleted in Hf. Thus, starting from an unique primordial mantle with chondritic $\mathrm{Lu}$ and $\mathrm{Hf}$ isotopic composition, which is referred as CHUR (Chondritic Uniform Reservoir) composition, two reservoirs with different $\mathrm{Lu} / \mathrm{Hf}$ ratio were generated: the crust with $\mathrm{Lu} /$ $\mathrm{Hf}_{\text {crust }}<\mathrm{Lu} / \mathrm{Hf}_{\mathrm{CHUR}}$ and the depleted mantle with $\mathrm{Lu} /$ $\mathrm{Hf}_{\text {mantle }}>\mathrm{Lu} / \mathrm{Hf}_{\mathrm{CHUR}}$.

As for other isotope systems, the deviation of the ${ }^{176} \mathrm{Hf} /{ }^{177} \mathrm{Hf}$ from the chondritic (CHUR) values for a sample is indicated by the Epsilon $(\varepsilon)$ notation:

$$
\varepsilon_{\mathrm{Hf}}=\left[\frac{\left({ }^{176} \mathrm{Hf} /{ }^{177} \mathrm{Hf}\right)_{\text {sample }}}{\left({ }^{176} \mathrm{Hf} /{ }^{177} \mathrm{Hf}\right)_{\mathrm{CHUR}}}-1\right] \times 10^{4}
$$

while the model age is calculated referred to the Depleted Mantle by the following formula:

$$
\begin{aligned}
& \mathrm{Hf} \mathrm{T}_{\mathrm{DM}}=1 / \lambda \times \ln \\
& \times\left\{\frac{\left({ }^{176} \mathrm{Hf} /{ }^{177} \mathrm{Hf}\right)_{\text {sample }}-\left({ }^{176} \mathrm{Hf} /{ }^{177} \mathrm{Hf}\right)_{\mathrm{DM}}}{\left({ }^{176} \mathrm{Lu} /{ }^{177} \mathrm{Hf}\right)_{\text {sample }}-\left({ }^{176} \mathrm{Lu} /{ }^{177} \mathrm{Hf}\right)_{\mathrm{DM}}}+1\right\}
\end{aligned}
$$

Whereas a single stage TDM age is commonly calculated for whole rock analyses, for zircon studies a twostage TDM age is needed (Nebel et al. 2007).

The TDM age in zircon is calculated from the initial $\mathrm{Hf}$ isotopic composition of the zircon, using an average crustal $\mathrm{Lu} / \mathrm{Hf}$ ratio. The initial $\mathrm{Hf}$ composition of zircon represents the ${ }^{176} \mathrm{Hf} /{ }^{177} \mathrm{Hf}$ value calculated at the time the zircon crystallized, namely the U-Pb age previously obtained on the same crystal. Such model ages indicate the crustal residence time for the rocks that hosted the zircon.

It is evident the importance to carry out $\mathrm{U}-\mathrm{Pb}$ and $\mathrm{Lu}-\mathrm{Hf}$ measurements on the same portion of a zircon grain, in order to be able to recalculate the $\varepsilon_{\mathrm{Hf}}$ and $\mathrm{Hf}$ TDM values at the time of its crystallization.

\section{ANALYTICAL TECHNIQUES}

INSTRUMENTATION AND LA MC-ICP-MASS SPECTROMETRY

In this study we use a Thermo Neptune MC-ICP-MS instrument equipped with an array of eight moveable Faraday collectors (L4, L3, L2, L1, H1, H2, H3, H4) and one fixed center collector (C), which supports a Faraday and a Secondary Electron Multiplier (SEM). The Neptune is also equipped with six Multiple Ion Counting (MICs), four of these associated to the L4 Faraday and two associated to the L3 and H4 Faradays, respectively.

All the measurements were performed in a static multi-collection and low mass resolution mode. The Faradays configuration for Lu-Hf measurements are shown in Table I.

\section{Standard Solutions Analyses}

In terms of signal stability, the ICP-MS solution system (solution sample) has more accuracy than laser ablation analyses; so, before starting the laser ablation sessions, we routinely calibrate the spectrometer with solutions. For this reason, the first objective in the development of this systematic has been to prepare a Hf standard solution.

For the preparation of the Hf standard solution, the SRM reference material JMC475, available as oxide $\mathrm{HfO}_{2}$, has been used. Firstly, we dissolved $100 \mathrm{mg}$ of $\mathrm{HfO}_{2}$ oxide in fluorhydric and nitric acid $\left(\mathrm{HF}+\mathrm{HNO}_{3}\right)$ 
TABLE I

Neptune Faraday cup configuration for Lu-Hf measurements.

\begin{tabular}{c|c|c|c|c|c|c|c|c}
\hline L4 & L3 & L2 & L1 & C & H1 & H2 & H3 & H4 \\
\hline${ }^{171} \mathrm{Yb}$ & ${ }^{173} \mathrm{Yb}$ & ${ }^{175} \mathrm{Lu}$ & ${ }^{176} \mathrm{Hf}$ & ${ }^{177} \mathrm{Hf}$ & ${ }^{178} \mathrm{Hf}$ & ${ }^{179} \mathrm{Hf}$ & ${ }^{180} \mathrm{Hf}$ & \\
\hline & & & ${ }^{176} \mathrm{Lu}$ & & & & & \\
\hline & & & ${ }^{176} \mathrm{Yb}$ & & & & & \\
\hline
\end{tabular}

to complete dissolution. Then, we prepared a $1000 \mathrm{ppm}$ stock solution and, starting from this, a 1 ppm sub-stock solution and a $200 \mathrm{ppb}$ solution for analyses have been produced.

With the aim to test the corrections for $\mathrm{Lu}$ and $\mathrm{Yb}$ isobaric interference and mass-bias fractionation, a portion of the prepared JMC475 standard solution has been doped with a known quantity of $\mathrm{Yb}$ and $\mathrm{Lu}$, obtaining a new standard solution with $\mathrm{Yb} / \mathrm{Hf}=0.02$ and $\mathrm{Lu} / \mathrm{Hf}=0.02$. At the beginning of each analytical session, the JMC475 standard solution is ran to calibrate the instrument until the reported values of ${ }^{176} \mathrm{Hf} /{ }^{177} \mathrm{Hf}$ are achieved.

The JMC475 isotopic values of Hf reported in the literature (Wu et al. 2006, Chu et al. 2002) were reproduced within error margins. In Figure 1 a typical result for a 240 cycles analysis of JMC475 standard solution is shown.

\section{Laser Ablation Analyses}

\section{- Sample Preparation}

Zircons are separated with density and gravimetric methods, and the preparation of polished mounts of epoxy resin with a number of zircon ranging from 10 to 100 , depending on the purpose of the analysis, is carried out.

As explained before, the measurement of Lu-Hf isotopes on zircons is made on a crystal previously analyzed by laser ablation U-Pb method to obtain age information. Spatially, the two spot analyses have to be as close as possible in order to analyze portions of the zircon grain with the same isotopic characteristics.

Before the in situ analysis, we should obtain as more information as possible about the structure of the zircon, such as zoning composition, growth pattern and presence of inherited core. It should prevent to analyses of portions of the zircon with different $\mathrm{Hf}$ and $\mathrm{Pb}$ isotopic compositions that would generate misleading results.
The best methods to obtain images of the internal structure of zircon on polished surfaces are the Cathodoluminescence (CL) and the Back-Scattered Electrons (BSE) techniques. For the Lu-Hf method, the BSE imagery is preferable because the brightness of the image is atomic mass dependent and, for that, it is possible to easily discriminate regions with different Hf content in the same zircon crystal. Higher brightness in the image corresponds to higher Hf contents in the zircon (Hanchar and Miller 1993, Corfu et al. 2003).

\section{- Laser Settings}

For U-Pb method, we utilized the laser configuration described in Bühn et al. (2009), which employ a a raster ablation generated by a moving laser spot with a diameter of $30 \mu \mathrm{m}$. As the raster ablation does not consume much material and produce a low deep hole on the zircon surface, in some case it is possible to do the Lu-Hf analyses in the same local of the previous $\mathrm{U}-\mathrm{Pb}$ analyses.

For Lu-Hf method, we chose a laser configuration following the most recent literature (Gerdes and Zeh 2006, 2009). The ablation geometry that we used is a laser spot of 40 to $55 \mu \mathrm{m}$ (Fig. 2), which, while reducing the spatial resolution, permits to ablate more material for a higher signal. To improve the stability of the signal, we chose a low laser frequency of about 5-7 Hz. The power of the laser used during the analytical session depends mainly on the Hf contents of the analyzed zircons, especially the standard one. In our case, using th GJ standard zircon, we used a power of about $40-50 \%$, which corresponds to an energy of $1-3 \mathrm{~J} / \mathrm{cm}^{2}$.

Helium flux is used to transport the ablated material from the zircon in the sample chamber to the MCICP-MS: a flux of about $0.38-0.46 \mathrm{lit} / \mathrm{min}$ is utilized depending on the values of the other laser parameters. The Helium flux has to be calibrated together with the Sam- 


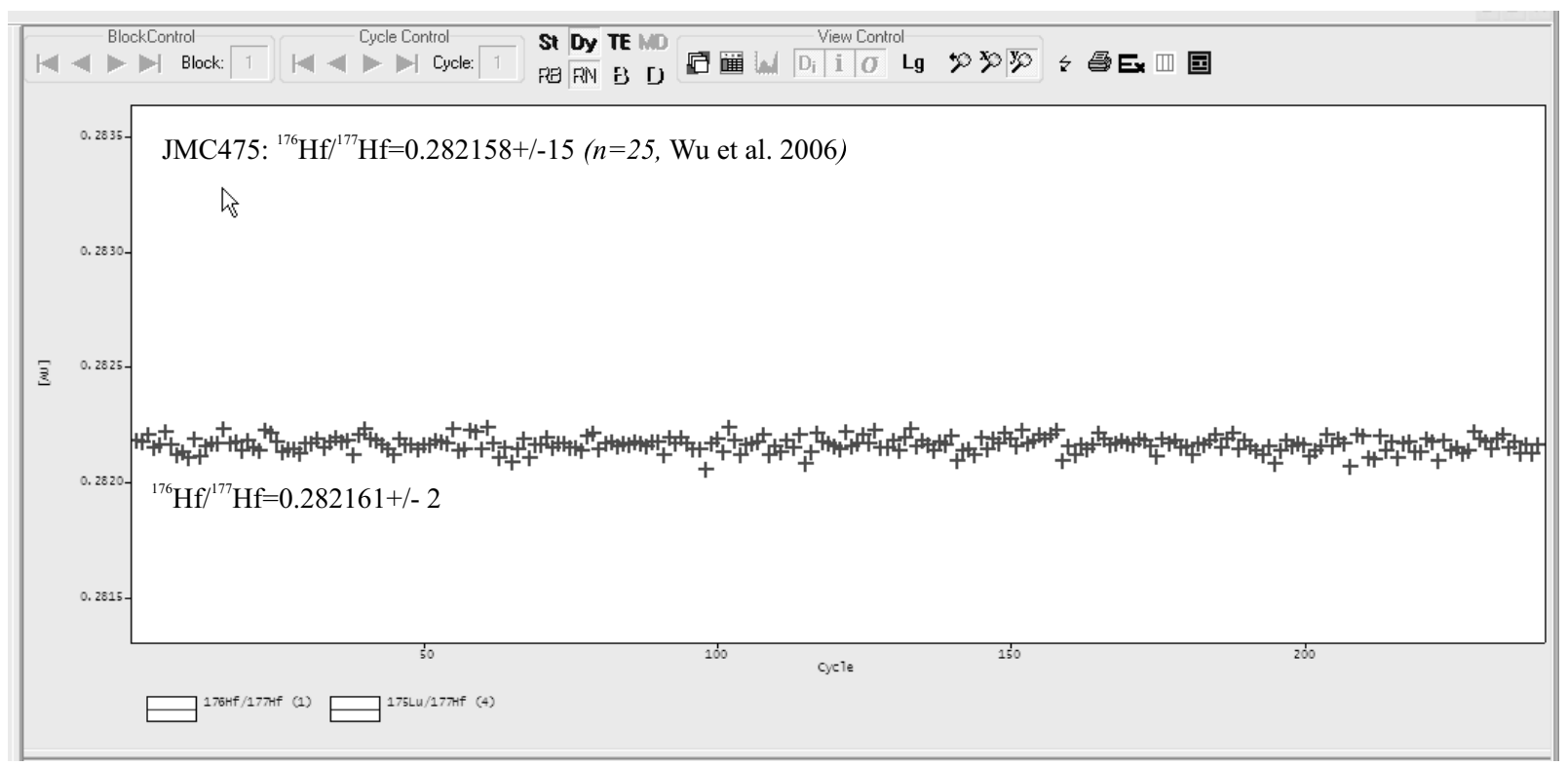

Fig. 1 - Typical analyses of JMC475 standard solution ( 6 blocks of 40 cycles of 4.034 seconds each). Mean value for JMC475 reported in literature and result of analysis are shown.

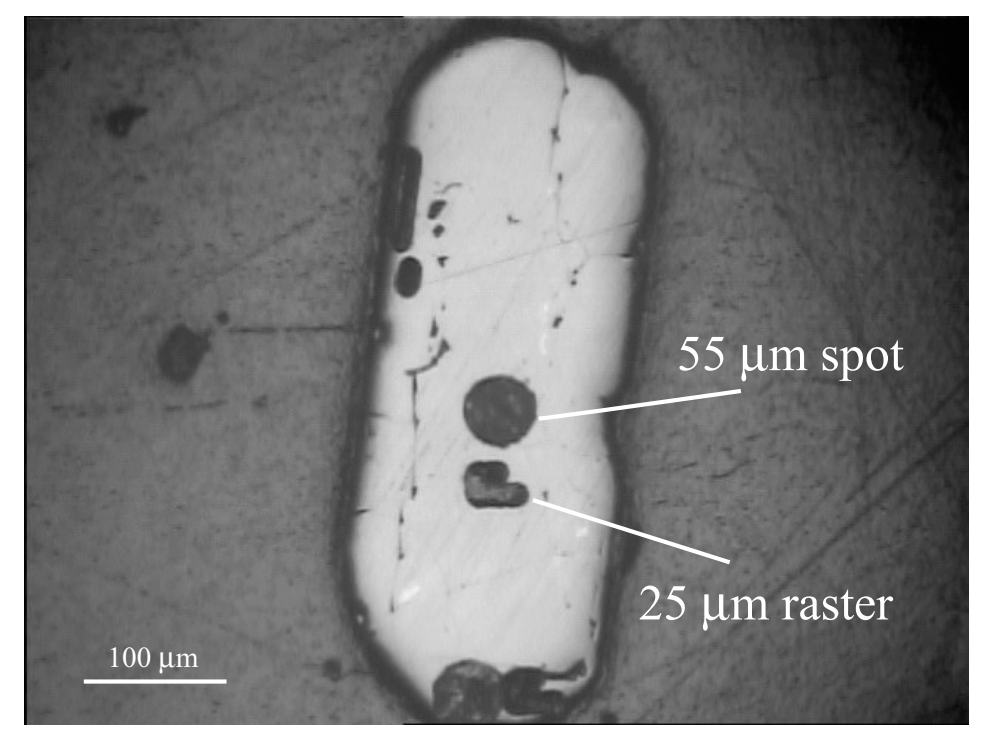

Fig. 2 - Example of zircon with two types of laser ablation pits produced by $25 \mathrm{~mm}$ raster and $55 \mathrm{~mm}$ spot modes, for $\mathrm{U}-\mathrm{Pb}$ and Lu-Hf methods respectively. Laser spot for scale.

ple gas (or Spare gas), which aids the sample to entry the plasma, and, so, obtaining the higher and more stable signal.

\section{SAMPLES}

Three different standard zircons (GJ-1, TEMORA 2 and UQ-Z) have been analyzed by laser ablation to repro- duce their Hf isotopic compositions. The standards are: (i) GJ-1 zircon standard (Jackson et al. 2004) provided by the ARC National Key Centre for Geochemical Evolution and Metallogeny of Continents (GEMOC), Australia; this is a gem-quality zircon crystal of about $0.7 \mathrm{~cm}$ in diameter, which was broken and prepared for analysis; (ii) Temora 2 (Black et al. 2004), provided by Lance 
Black, Geoscience Australia, Australia, which comes from the Middledale gabbroic diorite in the Eastern Australia; the zircon crystals have a size of about 300$500 \mu \mathrm{m}$ and, prior to sample preparation, the concentrate was hand-picked to obtain a high-purity zircon concentrate; iii) UQ-Z (Machado et al. 1996) provided by Alfonso Schrank, UNICAMP, Brazil. With the aim to characterize an in-house standard zircon for $\mathrm{U}-\mathrm{Pb}$ and Lu-Hf methods, a gem-type zircon from Madagascar (sample MADA) has been also analyzed. This zircon was provided by the Mineralogy Museum of Pisa University, Italy. For an example of geological application, two complex zircons from a paleoproterozoic migmatite from the Borborema Province were analyzed.

\section{RESULTS}

\section{DATA REDUCTION}

\section{$\mathrm{U}-\mathrm{Pb}$}

The analyses have been carried out using raster ablation method (Bühn et al. 2009) to prevent laser induced mass bias fractionation. The U-Pb raw data are translated to an Excel spreadsheet for data reduction and, when necessary, we corrected the laser induced mass bias using the method of Košler et al. (2002). Common lead $\left({ }^{204} \mathrm{~Pb}\right)$ interference and background correction, when necessary were carried out by monitoring the ${ }^{202} \mathrm{Hg}$ and 204 mass $\left({ }^{204} \mathrm{Hg}+{ }^{204} \mathrm{~Pb}\right)$ during the analytical sessions and using a model $\mathrm{Pb}$ composition (Stacey and Kramers 1975) when necessary. Reported errors are propagated by quadratic addition $\left[\left(2 \mathrm{SD}^{2}+2 \mathrm{SE}^{2}\right)^{1 / 2}\right]$ of external reproducibility and within-run precision: the external reproducibility is represented by the standard deviation (SD) obtained by repeated analyses $(n=20$, $\sim 0.8 \%$ for ${ }^{207} \mathrm{~Pb} / 206 \mathrm{~Pb}$ and $\sim 1 \%$ for ${ }^{206} \mathrm{~Pb} /{ }^{238} \mathrm{U}$ ) of standard zircon GJ-1, performed during analytical session, and the within-run precision is represented by the standard error (SE) that was calculated for each analysis. Concordia diagrams ( $2 \sigma$ error ellipses), concordia ages and lower and upper intercept ages were calculated using Isoplot/Ex (Ludwig 2001).

\section{$L u-H f$}

The acquired $\mathrm{Lu}$ and $\mathrm{Hf}$ isotope data are corrected online for mass bias fractionation and isobaric interfer- ences. Successively, the isotope ratios are translated to an Excel spreadsheet, for calculation of the parameters of geologic interest, as $\varepsilon_{\mathrm{Hf}}$ and $\mathrm{Hf}_{\mathrm{DM}}$ model age. The signals of the interference-free isotopes ${ }^{171} \mathrm{Yb},{ }^{173} \mathrm{Yb}$ and ${ }^{175} \mathrm{Lu}$ are monitored during the analyses in order to remove isobaric interferences of ${ }^{176} \mathrm{Yb}$ and ${ }^{176} \mathrm{Lu}$ on ${ }^{176} \mathrm{Hf}$ signal (Table I). The ${ }^{176} \mathrm{Yb}$ and ${ }^{176} \mathrm{Lu}$ contribution are calculated using the isotopic abundance of $\mathrm{Lu}$ and Hf proposed by Chu et al. (2002). The contemporaneous measurements of ${ }^{171} \mathrm{Yb},{ }^{173} \mathrm{Yb}$ permit to correct the mass bias fractionation of $\mathrm{Yb}$ using a ${ }^{173} \mathrm{Yb} /{ }^{171} \mathrm{Yb}$ normalization factor of 1.132685 (Chu et al. 2002). The $\mathrm{Hf}$ isotope ratios are normalized to ${ }^{179} \mathrm{Hf} /{ }^{177} \mathrm{Hf}$ value of 0.7325 (Chu et al. 2002). Our routine laser ablation measurements consist of 1 block of 40 cycles with an integration time of 1.034 seconds. For solution analyses, 4 blocks of 40 cycles and an integration time of 4 seconds are employed.

The $\varepsilon \operatorname{Hf}(\mathrm{t})$ values are calculated using the decay constant $\lambda=1.86 * 10^{-11}$, proposed by Scherer et al. (2001) and the ${ }^{176} \mathrm{Lu} /{ }^{177} \mathrm{Hf}$ and ${ }^{176} \mathrm{Hf} /{ }^{177} \mathrm{Hf} \mathrm{CHUR}$ values of 0.0332 and 0.282772 proposed by Blichert-Toft and Albaréde (1997). The two stages depleted mantle Hf model ages (TDM Hf) are calculated using ${ }^{176} \mathrm{Lu} /$ ${ }^{177} \mathrm{Hf}=0.0384$ and ${ }^{176} \mathrm{Hf} /{ }^{177} \mathrm{Hf}=0.28325$ for the depleted mantle (Chauvel and Blichert-Toft 2001) and ${ }^{176} \mathrm{Lu} /{ }^{177} \mathrm{Hf}$ value of 0.0113 for the average crust (Taylor and McLennan 1985, Wedepohl 1995).

\section{StANDARd Zircon ANALYSES}

The GJ-1 zircon standard has been analyzed over a period of about six months. The obtained Hf isotopic compositions yielded ${ }^{176} \mathrm{Hf} /{ }^{177} \mathrm{Hf}=0.282022 \pm 11$ (2SD, $\mathrm{n}=56$ ), reproducing within the error margins the values reported in literature by several authors (Elhlou et al. 2006, Zeh et al. 2007). The Temora-2, UQ-Z zircon standards and MADA zircon have been analyzed in several analytical sessions. The obtained results are listed in Table II. The Temora-2 isotopic composition yielded ${ }^{176} \mathrm{Hf} /{ }^{177} \mathrm{Hf}=0.282693 \pm 14$ (2SD, $\left.\mathrm{n}=25\right)$, in agreement with the values reported in the literature by Woodhead et al. (2004), Hawkesworth and Kemp (2006) and Wu et al. 2006.

The analyses carried out on the UQ-Z zircons standard yielded ${ }^{176} \mathrm{Hf} /{ }^{177} \mathrm{Hf}=0.282127 \pm 33(2 \mathrm{SD}, \mathrm{n}=11)$, 
TABLE II

Mean Hf isotopic compositions for zircon standards obtained by LA-MC-ICP-MS.

\begin{tabular}{c|c|c|c|c|c|c|c}
\hline Sample & ${ }^{176} \mathrm{Lu} /{ }^{177} \mathrm{Hf}$ & $2 \sigma$ & ${ }^{176} \mathrm{Hf} /{ }^{177} \mathrm{Hf}$ & $2 \sigma$ & $\varepsilon_{\mathrm{Hf}}$ & $2 \sigma$ & $\mathrm{T}_{\mathrm{DM}(\mathrm{Ga})}$ \\
\hline GJ-1 $(\mathrm{n}=56)$ & 0.000296 & 4 & 0.282022 & 11 & -13.35 & 0.35 & 2.12 \\
\hline Temora 2 $(\mathrm{n}=25)$ & 0.00123 & 15 & 0.282693 & 14 & +6.02 & 0.48 & 0.89 \\
\hline UQ-Z $(\mathrm{n}=11)$ & 0.00044 & 13 & 0.282147 & 33 & +2.70 & 0.88 & 1.65 \\
\hline MADA $(\mathrm{n}=14)$ & 0.00019 & 10 & 0.282352 & 22 & -2.15 & 0.8 & 1.48 \\
\hline
\end{tabular}

showing a very homogeneous Hf composition. Before the analytical session, the MADA zircon has been previously studied with the BSE technique in order to evaluate a possible growth zoning. The BSE image obtained for the analyzed grain shows that it is very homogeneous in terms of Hf content, do not showing any internal structures. The Hf analyses carried out in different parts of the grain yielded ${ }^{176} \mathrm{Hf} /{ }^{177} \mathrm{Hf}=0.282352 \pm 22$ ( $2 \mathrm{SD}, \mathrm{n}=14)$, suggesting a very homogeneous $\mathrm{Hf}$ isotopic composition.

\section{Example of Geological Application}

We present an application study of the in situ combined $\mathrm{U}-\mathrm{Pb}$ and Lu-Hf systematic on zircons with LA-(MC) ICP-MS technique. This study has been chosen to show the potential of the Lu-Hf LA-MC-ICP-MS systematic on zircon as a powerful tool for reconstructing the tectonic evolution of a cratonic area.

The studied zircons have been separated from a leucocratic portion of migmatitic rock from the Rio Grande do Norte terrain in the Borborema Province. Images of the selected zircons in backscattered electrons (BSE) mode were obtained using a Scanning Electron Microprobe (SEM) in order to have information on the internal structure of the studied zircons. In this contribution, we employ the BSE technique using a Scanning Electron Microscope (SEM) JOEL of the laboratory of the Federal Police of Brasília.

The BSE images permitted us to differentiate Hfrich and Hf-poor portions of zircons, characterized by high and low brightness response, respectively.

The studied zircons show a typical flat shaped metamorphic morphology and complex internal structures (Fig. 3), with well developed zoning with an euhedral Hf-rich core rimmed by a Hf-poor rim.

We analyzed the selected zircons with combined U-
$\mathrm{Pb}$ and Lu-Hf in situ LA-MC-ICP-MS technique (Tables III and IV). Every portion of each zircon grains showing peculiar and distinctive characteristics based on the interpretation of BSE images has been analyzed. Initial Hf composition for each zircon has been calculated using the U-Pb age of the correspondent spot. For old discordant zircons, it was assumed that ${ }^{207} \mathrm{~Pb} /{ }^{206} \mathrm{~Pb}$ age represents the crystallization age, whereas for younger zircons the ${ }^{206} \mathrm{~Pb} /{ }^{238} \mathrm{U}$ was considered. The Lu-Hf data are shown in Table IV.

In Figure 4 the Concordia diagrams for the obtained data on two zircons are shown. The two analyses of zircon 1 (Fig. 4a) define two crystallization events: an older one defined by a ${ }^{207} \mathrm{~Pb} /{ }^{206} \mathrm{~Pb}$ age of $2057 \pm 14 \mathrm{Ma}$, and a younger one defined by the concordant age of $578 \pm 11$. The U-Pb analyses on zircon 12 also define (Fig. $4 \mathrm{~b}$ ) two crystallization events individuated by a concordant analysis of $2024 \pm 11 \mathrm{Ma}$ and a by a slightly discordant analyses with ${ }^{206} \mathrm{~Pb} /{ }^{238} \mathrm{U}$ age of $606 \pm 15 \mathrm{Ma}$. In Figure $4 \mathrm{c}$ a graphic interpretation of the slightly discordant rim data for zircon 12 is shown.

The distribution of these younger analyses may be interpreted in two different ways: i) different extreme $\mathrm{Pb}$-loss of Paleoproterozic grains induced by a $575 \mathrm{Ma}$ magmatic event (Dantas et al. 2004) and ii) crystallization event at $575 \mathrm{Ma}$, with discordance for zircon 12 rim possibly caused by an imperfect sample preparation. In this case, as shown in Figure 4c, it is possible that the laser accidentally ablated a portion of the older core. The total signal of such analysis, representing a mixing of two different portions of the zircons, would be plotted on a discordia line defined by the two different (end-members) $\mathrm{U}-\mathrm{Pb}$ isotopic compositions.

The Hf results are listed in Table IV and shown in the diagram of Figure 5a-b. The zircon 1 shows very homogeneous $\mathrm{Hf}$ composition with ${ }^{176} \mathrm{Hf} /{ }^{177} \mathrm{Hf}$ ratios 

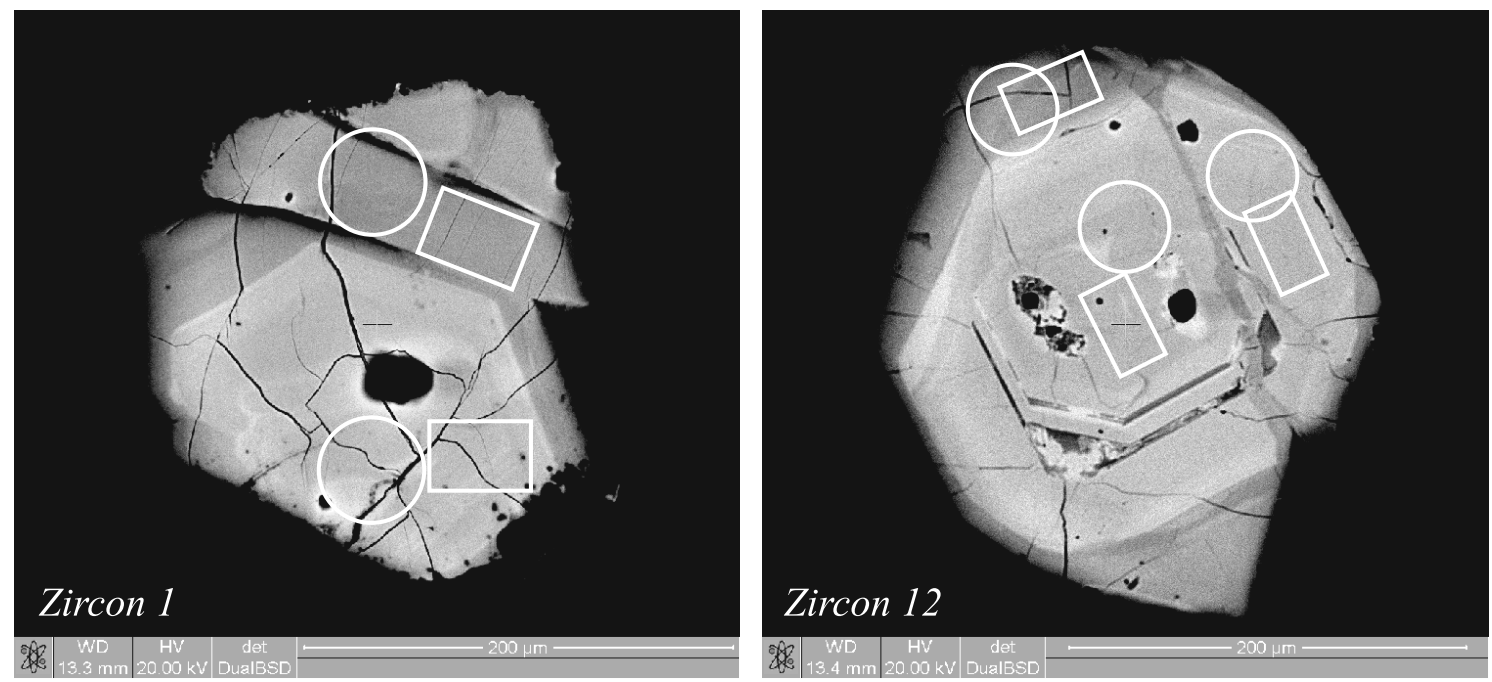

Fig. 3 - Backscattering images of studied zircons. White circles: Lu-Hf laser spot; white rectangle: U-Pb laser raster.

TABLE III

Results of in situ U-Pb LA-MC-ICP-MS zircons analyses.

\begin{tabular}{|c|c|c|c|c|c|c|c|c|c|c|c|c|c|c|}
\hline \multirow[b]{2}{*}{ Sample } & \multirow[b]{2}{*}{ Site } & \multirow{2}{*}{$\begin{array}{l}{ }^{207} \mathrm{~Pb} / \\
{ }^{206} \mathrm{~Pb}\end{array}$} & \multirow[b]{2}{*}{$\begin{array}{l}2 \sigma \\
(\%)\end{array}$} & \multirow{2}{*}{$\begin{array}{c}{ }^{206} \mathrm{~Pb} / \\
{ }^{238} \mathrm{U}\end{array}$} & \multirow[b]{2}{*}{$\begin{array}{l}2 \sigma \\
(\%)\end{array}$} & \multirow{2}{*}{$\begin{array}{c}{ }^{207} \mathrm{~Pb} / \\
{ }^{235} \mathrm{U}\end{array}$} & \multirow[b]{2}{*}{$\begin{array}{l}2 \sigma \\
(\%)\end{array}$} & \multicolumn{7}{|c|}{ Apparent ages (Ma) } \\
\hline & & & & & & & & $\begin{array}{l}{ }^{207} \mathrm{~Pb} / \\
{ }^{206} \mathrm{~Pb}\end{array}$ & $\begin{array}{c}2 \sigma \\
(\mathrm{abs})\end{array}$ & $\begin{array}{c}{ }^{206} \mathrm{~Pb} / \\
{ }^{238} \mathrm{U}\end{array}$ & $\begin{array}{c}2 \sigma \\
(\mathrm{abs})\end{array}$ & $\begin{array}{c}{ }^{207} \mathrm{~Pb} / \\
{ }^{235} \mathrm{U}\end{array}$ & $\begin{array}{c}2 \sigma \\
(\mathrm{abs})\end{array}$ & Rho \\
\hline Zircon 1 & core & 0.127 & 0.8 & 0.322 & 6.0 & 5.632 & 6.1 & 2057.1 & 14.3 & 1797.6 & 94.5 & 1921.1 & 52.4 & 0.99 \\
\hline Zircon 1 & rim & 0.059 & 1.1 & 0.093 & 2.5 & 0.766 & 2.7 & 584.5 & 26.1 & 575.5 & 14.1 & 577.3 & 12.4 & 0.92 \\
\hline Zircon 12 & core & 0.121 & 0.8 & 0.316 & 3.0 & 5.273 & 3.1 & 1970.7 & 14.5 & 1770.9 & 45.9 & 1864.6 & 26.2 & 0.96 \\
\hline Zircon 12 & core & 0.124 & 0.7 & 0.362 & 2.5 & 6.210 & 2.6 & 2020.4 & 11.7 & 1991.6 & 42.9 & 2005.8 & 22.6 & 0.97 \\
\hline Zircon 12 & rim & 0.065 & 1.3 & 0.099 & 2.7 & 0.881 & 3.0 & 768.0 & 27.4 & 606.3 & 15.5 & 641.6 & 14.2 & 0.90 \\
\hline
\end{tabular}

TABLE IV

Results of in situ Lu-Hf LA-MC-ICP-MS analyses.

\begin{tabular}{c|c|c|c|c|c|c|c|c|c|c}
\hline Sample & Site & ${ }^{176} \mathrm{Lu} /{ }^{177} \mathrm{Hf}$ & $\mathrm{SE}$ & ${ }^{176} \mathrm{Hf} /{ }^{177} \mathrm{Hf}$ & $\mathrm{SE}$ & Age $(\mathrm{Ma})$ & $\left({ }^{176} \mathrm{Hf} /{ }^{177} \mathrm{Hf}\right) \mathrm{t}$ & $\mathrm{SE}$ & $\varepsilon_{\mathrm{Hf}}(\mathrm{t})$ & $\mathrm{T}_{\mathrm{DM}}(\mathrm{Ga})$ \\
\hline Zircon 1 & core & 0.000783 & \pm 38 & 0.281405 & \pm 36 & $2057^{* *}$ & 0.281373 & \pm 36 & -2.73 & 2.68 \\
\hline Zircon 1 & rim & 0.000420 & \pm 4 & 0.281401 & \pm 33 & $578^{*}$ & 0.281396 & \pm 33 & -35.5 & 3.32 \\
\hline Zircon 12 & core & 0.000332 & \pm 1 & 0.281356 & \pm 28 & $1970^{* *}$ & 0.281343 & \pm 28 & -6.1 & 2.79 \\
\hline Zircon 12 & core & 0.000533 & \pm 6 & 0.281348 & \pm 41 & $2020^{* *}$ & 0.281327 & \pm 41 & -6.6 & 2.82 \\
\hline Zircon 12 & rim & 0.000443 & \pm 3 & 0.281331 & \pm 27 & $606^{*}$ & 0.281326 & \pm 27 & -37.9 & 3.46 \\
\hline \multicolumn{10}{c}{$* 206 \mathrm{~Pb} /{ }^{238} \mathrm{U}$ age. $/ * * 207 \mathrm{~Pb} /{ }^{206} \mathrm{~Pb}$ age. }
\end{tabular}

of 0.281405 and 0.281401 , and $\varepsilon \mathrm{Hf}_{(t)}$ of -2.73 and -35.5 for the core and rim, respectively. The analyzed core portions of zircon 12 with Paleoproterozoic ${ }^{207} \mathrm{~Pb} /$ ${ }^{206} \mathrm{~Pb}$ apparent ages have homogeneous Hf isotope composition with measured ${ }^{176} \mathrm{Hf} /{ }^{177} \mathrm{Hf}$ ratios of 0.281348 and 0.281356 , and $\varepsilon \mathrm{Hf}_{(t)}-6.6$ to -6.1 , respectively. The rim with neoproterozoic ${ }^{206} \mathrm{~Pb} /{ }^{238} \mathrm{U}$ age gave similar $\mathrm{Hf}$ compositions with ${ }^{176} \mathrm{Hf} /{ }^{177} \mathrm{Hf}$ ratio of 0.281331 and $\varepsilon$ Hf of -38). The TDM Hf model ages for the Paleoproterozoic cores of the two analyzed zircons are similar, ranging between 2.68 and $2.82 \mathrm{Ga}$. The Neoproterozoic rims have been characterized by older TDM Hf model ages of 3.32 and 3.46 Ga for zircon 1 and zircon 12 , respectively.

The Hf isotope composition evolution diagram shows that the Paleoproterozoic cores crystallized at 

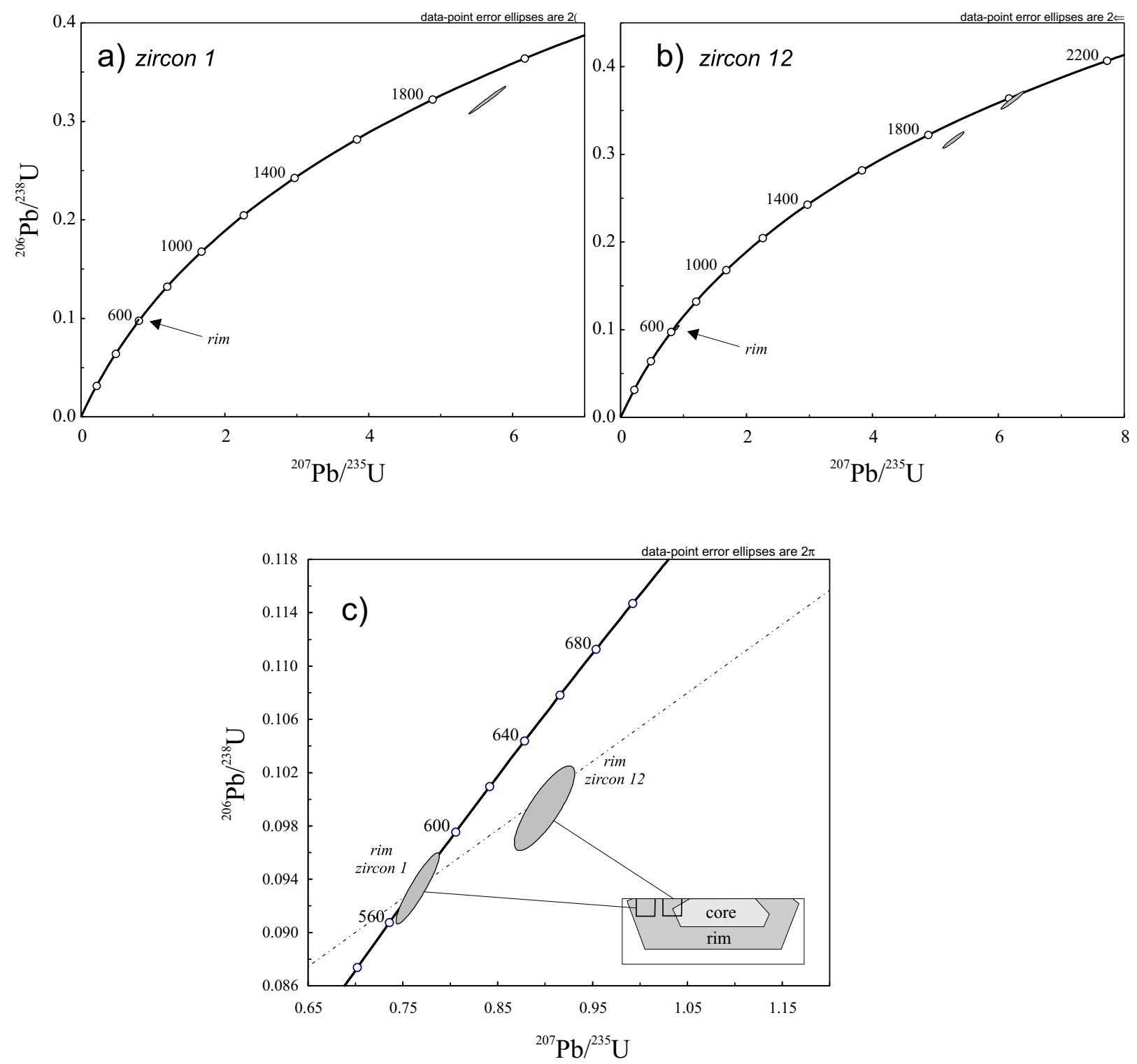

Fig. $4-\mathrm{a}-\mathrm{b}$ ) Concordia diagrams showing the U-Pb results obtained for the two selected zircons from the studied migmatite rock. c) Detail of the lower intercept portions, showing the rim compositions of both analyzed zircons. In the frame an analytical interpretation for discordant characters of one of these analyses is showed (see text for discussion).

$\sim 2.05 \mathrm{Ga}$ in magmas characterized by an important crustal signature. These magmas may have been formed by partial melting of an older juvenile crust generated at 2.5-2.8 Ga or, alternatively, may represent juvenile magmas generated at 2.0-2.2 Ga and contaminated by older (Archean) crustal material. In the diagrams of Figure $5 \mathrm{a}-\mathrm{b}$, the evolution of $\mathrm{Hf}$ isotopic composition (calculated for $\mathrm{Lu} / \mathrm{Hf}=0.0113$ ) for different types of Paleoproterozoic to Archean juvenile crust are reported.
The Hf isotopic composition of Neoproterozic rims suggests that they could not crystallized in magma derived by partial melting of a 2.0-2.2 Ga Paleoproterozoic crust, represented by the older core of the studied zircons. To produce the measured Hf composition $\left(\varepsilon \mathrm{Hf}_{(\mathrm{t})} \sim 35, \mathrm{TDM}>3.2 \mathrm{Ga}\right)$ of the young rims, a more radiogenic isotopic component, derived from earlier (or older) Archean crust, has to be involved during the crystallization of the outer part of the studied zircons. 

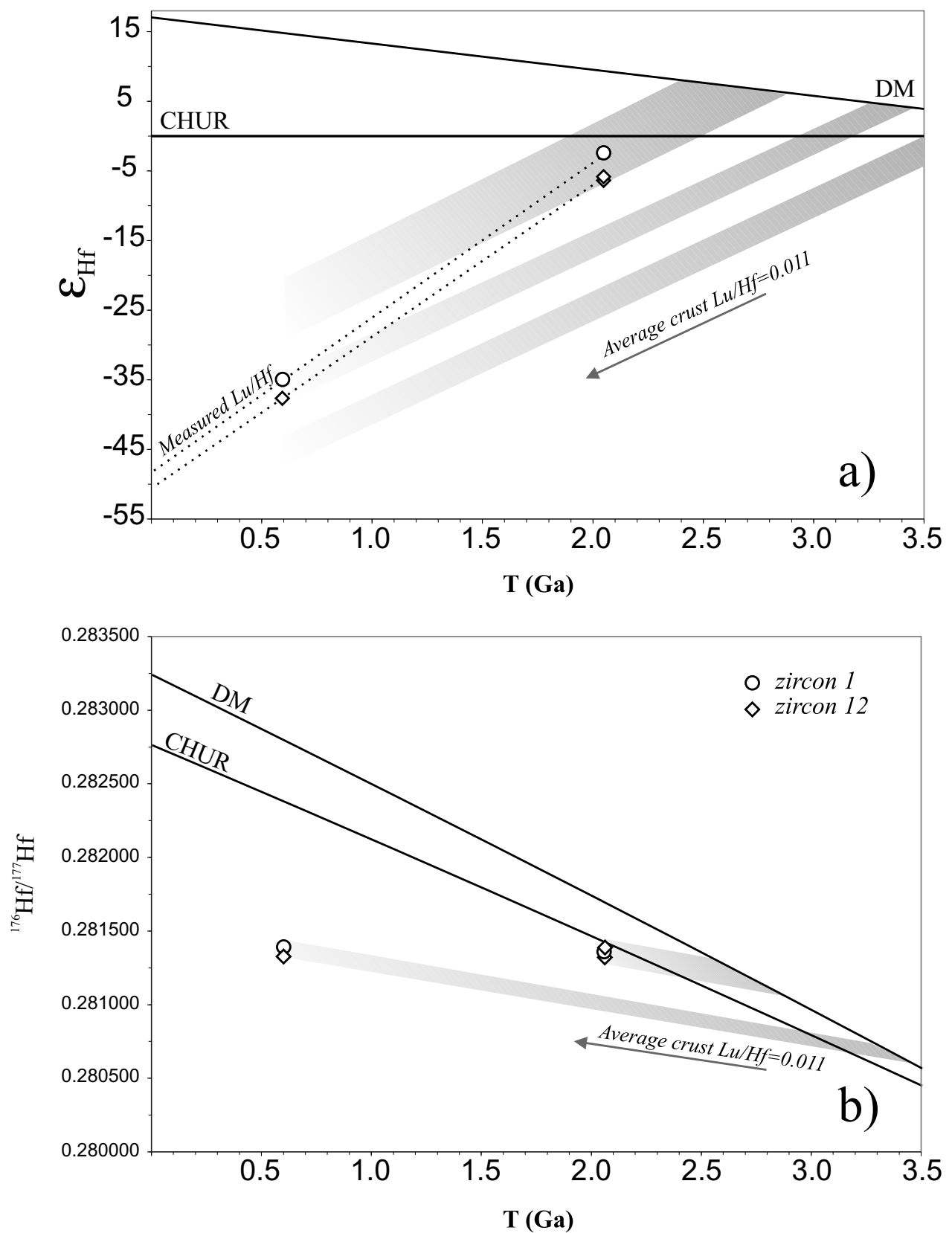

Fig. $5-\varepsilon_{\mathrm{Hf}}$ (a) and Hf isotope (b) evolution diagrams showing the results of Lu-Hf LA-MC-ICP-MS analyses. Shadowed areas indicate the $\varepsilon_{\mathrm{Hf}(\mathrm{t})}$ bulk-rock evolution trend for terranes of different ages recognised in the Borborema Province (Dantas et al. 2004). Dotted lines (Fig. 5a) indicate the $\varepsilon_{\mathrm{Hf}}(\mathrm{t})$ evolution for zircons crystallized at $\sim 2 \mathrm{Ga}$, calculated from measured Lu-Hf.

On the other hand, the zircons are characterized by practically the same values of ${ }^{176} \mathrm{Hf} /{ }^{177} \mathrm{Hf}$ ratio at the rim and the core. In the diagrams of Figure 5a, the $\mathrm{Hf}$ composition of the rims plot on the Hf isotopic evo- lution curve of the core portions of the same zircons, calculated from the measured ${ }^{176} \mathrm{Lu} /{ }^{177} \mathrm{Hf}$. Thus, these younger rims may be interpreted as a recrystallization of the outer part of the zircon grains during a Neoprotero- 
zoic high metamorphic/migmatitic event. This process would have reset almost entirely the U-Pb system, leaving unaltered the Hf isotopic composition.

\section{DISCUSSION AND CONCLUSIONS}

In this paper we described the systematic developed in the laboratory of geochronology of the University of Brasília for the combined in situ U-Pb and Lu-Hf analyses on zircons by LA-MC-ICP-MS. The Hf isotopic compositions for three zircon standards have been measured. The ${ }^{176} \mathrm{Hf} /{ }^{177} \mathrm{Hf}$ values for GJ-1 and TEMORA-2 reported in the literature by several authors have been reproduced, within error margin. The Lu-Hf isotopic composition for the zircon standard UQ-Z and for a in-house zircon standard is reported.

New U-Pb and Lu-Hf isotopic data were obtained for two zircons selected from a migmatitic rock from the Borborema Province. The U-Pb, Lu Hf in situ analyses, combined with BSE imaging, permitted to study in detail the internal isotopic composition of the zircons and to obtain information about the growing history of each zircon. On the basis of U-Pb and Lu-Hf data, two main crystallization events have been identified in both studied zircons. An older event at ca. 2.05 Ga that was recognized in the core portions of the zircons represents a well characterized Paleoproterozoic magmatic event that affected the whole Borborema Province. A second younger crystallization event at $\sim 575 \mathrm{Ma}$, which generated the rim portions of the zircons, would represent a high grade metamorphic-magmatic, in agreement with previous geochronological data obtained by other authors (Dantas et al. 2004) on monazite (TIMS) from a granite outcropping in the same region.

\section{ACKNOWLEDGMENTS}

The LA-MC-ICP-MS facility was installed at the University of Brasília with funds provided by PETROBRAS and the Ministry of Minas e Energia of Brazil. This work is part of the postdoctoral research of the first author. Financial support from Conselho Nacional de Desenvolvimento Científico e Tecnológico (CNPq), Grant N. 150142/2007-2, is acknowledged. We thank Prof. Roberto Ventura Santos, University of Brasília, for providing JMC475 Hf standard material.

\section{RESUMO}

O sistema isotópico Lutécio-Hafnio representa uma das ferramentas mais recentes e poderosas para estudos isotópicos e geocronológicos. Análises combinadas in situ de U-Pb e Lu-Hf sobre zircão pelo LA-MC-ICP-MS permitem caracterizar isotopicamente o magma onde ele cristalizou, fornecendo valiosas informações para estudos de proveniência de sedimento e de evolução crustal. Nesse trabalho descrevemos a sistemática de Lu-Hf pelo LA-MC-ICP-MS implantada no laboratório de Geocronologia da Universidade de Brasília e reportamos os resultados obtidos de repetidas análises de três padrões de zircão: GJ-1 $=0.282022 \pm 11(2 \mathrm{SD}, \mathrm{n}=56)$, Temora $2=0.282693 \pm$ $14(2 \mathrm{SD}, \mathrm{n}=25)$ and $\mathrm{UQ}-\mathrm{Z}=0.282127 \pm 33(2 \mathrm{SD}, \mathrm{n}=11)$. Foi também caracterizada a razão isotópica ${ }^{176} \mathrm{Hf} /{ }^{177} \mathrm{Hf}(0.282352$ $\pm 22,2 \mathrm{SD}, \mathrm{n}=14$ ) de um zircão usado como padrão interno do laboratório. Como aplicação geológica, analisamos dois zircões complexos selecionados a partir de uma amostra de migmatito da Província de Borborema, NE do Brasil. Sobre a base dos dados U-Pb e Lu-Hf foram identificados em ambos os zircões dois eventos de cristalização. Um evento mais antigo de 2.05 Ga nos núcleos herdados, representa um evento magmático Paleoproterozoico bem conhecido na Província Borborema. Um segundo evento de $\sim 575 \mathrm{Ma}$, reconhecido nas bordas, representa um evento magmático-metamórfico Neoproterozóico (Brasiliano).

Palavras-chave: LA-MC-ICP-MS, Lu-Hf, U-Pb, zircão, Província de Borborema.

\section{REFERENCES}

BLACK LP ET AL. 2004. Improved ${ }^{206} \mathrm{~Pb} /{ }^{238} \mathrm{U}$ microprobe geochronology by the monitoring of a trace-element-related matrix effect: SHRIMP, ID-TIMS, ELA-ICP-MS and oxygen isotope documentation for a series of zircon standards. Chem Geol 205: 115-140.

Blichert-Toft JE And Albaréde F. 1997. The Lu-Hf isotope geochemistry of chondrites and the evolution of the mantle-crust system. Earth Planet Sci Lett 148: 243258.

Bühn B, Pimentel MM, Matteini M and Dantas EL. 2009. High spatial resolution analysis of $\mathrm{Pb}$ and $\mathrm{U}$ isotopes for geochronology by laser ablation multi-collector inductively coupled plasma mass spectrometry (LA-MCICPMS). An Acad Bras Cienc 81: 99-114.

Chauvel C And Blichert-Toft JE. 2001. A hafnium isotope and trace element perspective on melting of the depleted mantle. Earth Planet Sc Lett 190: 137-151. 
Cherniak DJ AND Watson EB. 2000. Pb diffusion in zircon. Chem Geol 172: 5-24.

Cherniak DJ, HANChar JM AND WATSON EB. 1997. Rare earths diffusion in zircon. Chem Geol 134: 289301.

Chu nC, Taylor Rn, Chavagnac V, Nesbitt RW, Boella RM, Milton JA, German CR, Bayon G AND BURTON K. 2002. Hf isotope ratio analysis using multi-collector inductively coupled plasma mass spectrometry: an evaluation of isobaric interference corrections. J Anal Atom Spectrom 17: 1567-1574.

CORfu F, Hanchar JM, Hoskin PWO AND KinNy P. 2003. Atlas of zircon textures. In: HANCHAR JM AND Hoskin PWO (Eds), Zircon, The Geological Society of America (GSA), Washington, USA, p. 468-500.

DANTAS EL, VAN SCHMUS WR, HACKSPACHER PC, BRIto Neves BB AND FetTer AH. 1999. Identification of Multiple Orogenic/metamorphic Events in Polycyclic Terranes: Possibilities and Limitations. Insights from the Borborema Province, NE Brasil. VII SNET, Lençóis, BA, p. $15-17$.

DANTAS EL, VAN SCHMUS WR, HACKSPACHER PC, FETTER AH, DE BRito NeVEs BB, CORDANi U, NutMAN AP AND Williams IS. 2004. The 3.4-3.5 Ga São José do Campestre massif, NE Brazil: remnants of the oldest crust in South America. Precambrian Res 130: 113-137.

Elhlou S, Belousova E, Griffin WL, Pearson NJ AND O'REILly SY. 2006. Trace element and isotopic composition of GJ-red zircon standard by laser ablation. Goldschmidt Conference abstracts, A-5.

Gerdes A AND ZeH A. 2006. Combined U-Pb and Hf isotope LA-(MC)-ICP-MS analyses of detrital zircons: comparison with SHRIMP and new constraints for the provenance and age of an Armorican metasediment in Central Germany. Earth Planet Sc Lett 249: 47-61.

Gerdes A AND ZEH A. 2009. Zircon formation versus zircon alteration - New insights from combined $\mathrm{U}-\mathrm{Pb}$ and Lu-Hf in-situ LA-ICP-MS analyses, and consequences for the interpretation of Archean zircon from the Central Zone of the Limpopo Belt. Chem Geol 261: 230-243.

Griffin WL, Pearson NJ, Belousova E, JaCkson SE, O'ReIlly SY, VAN ACHTERberg E AND SheE SR. 2000. The Hf isotope composition of cratonic mantle: LAM-MC-ICPMS analysis of zircon megacrysts in kimberlites. Geochim Cosmochim Ac 64: 133-147.

GrifFin WL, WANG X, JACKSON SE, PEARson SE, O'Reilly SY, Xu XS AND ZhOU XM. 2002. Zircon chemistry and magma genesis, SE China: in-situ analysis of Hf isotopes, Tonglu and PingtanIgneous Complexes. Lithos 61: 237-269.

Hanchar JM AND Miller CF. 1993. Zircon zonation patterns revealed by cathodoluminescence and backscattered electron images: implications for interpretation of complex crustal history. Chem Geol 110: 1-13.

HAWKESWORTH CJ AND KEMP AIS. 2006. Using hafnium and oxygen isotopes in zircons to unravel the record of crustal evolution. Chem Geol 226: 144-162.

Jackson SE, Pearson NJ, GrifFin WL and BelousoVA EA. 2004. The application of laser ablation inductively coupled plasma mass spectrometry to in situ $\mathrm{U}-\mathrm{Pb}$ zircon geochronology. Chem Geol 211: 47-69.

KINNY PD AND MAAS R. 2003. Lu-Hf and Sm-Nd isotope systems in zircon. In: HANCHAR JM AND HOSKIN PWO (Eds), Zircon, The Geological Society of America (GSA), Washington, USA, p. 327-341.

KoŠler J, Fonneland H, Sylvester P, Tubrett M AND PEDERSEN RB. 2002. U-Pb dating of detrital zircons for sediment provenance studies - a comparison of laser ablation ICMPS and SIMS techniques. Chem Geol 182: 605-618.

LUDWIG K. 2001. Isoplot/Ex, rev. 2.49. A Geochronological Toolkit for Microsoft Excel. Berkeley Geochronology Center, Special Publications N. 4, 70 p.

Machado N, Schrank A, Noce CM and Gauthier G. 1996. Ages of detrital zircon from Archean-Paleoproterozoic sequences: Implications for Greenstone Belt setting and evolution of a Transamazonian foreland basin in Quadrilátero Ferrífero, southeast Brazil. Earth Planet Sc Lett 141: 259-276.

Nebel O, Nebel-Jacobsen Y, Mezger K ANd Berndt J. 2007. Initial Hf isotope compositions in magmatic zircon from early Proterozoic rocks from the Gawler Craton, Australia: A test for zircon model ages. Chem Geol: 241: 23-37.

NIR-EL Y, AND LAVI N. 1998. Measurement of the half-life of ${ }^{176} \mathrm{Lu}$. Appl Radiat Isotopes 49: 1653.

Patchett PJ And Tatsumoto M. 1980. Hafnium isotope variations in oceanic basalts. Geophys Res Lett 7: 10771080.

Patchett PJ, Kouvo O, Hedge CE and Tatsumoto M. 1981. Evolution of continental crust and mantle heterogeneity: evidence from Hf isotopes. Contrib Mineral Petrol 78: 279-297.

Scherer E, MÜnKer C And Mezger K. 2001. Calibration of the lutetium-hafnium clock. Science 293: 683687. 
SGUigna AP, LARABEE AJ AND WAdDington JC. 1982. The half-life of ${ }^{176} \mathrm{Lu}$ by a c-c coincidence measurement. Can J Phys 60: 361-364.

StACEY JS AND KRAMERS JD. 1975. Approximation of terrestrial lead isotope evolution by a two-stage model. Earth Planet Sc Lett 26: 207-221.

TAYLOR SR AND MCLEnNAN SM. 1985. The Continental Crust: its Composition and Evolution. Oxford: Blackwell, $312 \mathrm{p}$.

Thirlwall MF AND WALder AJ. 1995. In situ hafnium isotope ratio analysis of zircon by inductively coupled plasma multiple collector mass spectrometry. Chem Geol 122: 241-247.

VERVOORT JD AND BLICHERT-TOFT J. 1999. Evolution of the depleted mantle: Hf isotope evidence from juvenile rocks through time. Geochim Cosmochim Ac 63: 533556.
WEDEPOHL KH. 1995. The compositions of the continental crust. Geochim Cosmochim Ac 59: 1217-1232.

Woodhead J, Hergt J, Shelley M, EgGins S AND KEMP R. 2004. Zircon Hf-isotope analysis with an excimer laser, depth profiling, ablation of complex geometries and concomitant age estimation. Chem Geol 209: 121-135.

Wu FY, Yang YH, Xie LW, Yang JH and XU P. 2006. $\mathrm{Hf}$ isotopic compositions of the standard zircons and baddeleyites used in U-Pb geochronology. Chem Geol 234 (1-2): 105-126.

Zeh A, Gerdes A, Klemd R AND Barton JR JM. 2007. Archaean to Proterozoic Crustal Evolution in the Central Zone of the Limpopo Belt (South Africa-Botswana): Constraints from Combined $\mathrm{U}-\mathrm{Pb}$ and $\mathrm{Lu}-\mathrm{Hf}$ Isotope Analyses of Zircon. J Petrol 48: 1605-1639. 